\title{
LXI. On the penetration of balls into uniform resisting substances
}

\section{W. Moore Esq.}

To cite this article: W. Moore Esq. (1810) LXI. On the penetration of balls into uniform resisting substances, Philosophical Magazine Series 1, 36:151, 325-334, DOI: 10.1080/14786441008563201

To link to this article: http://dx.doi.org/10.1080/14786441008563201

曲 Published online: 18 May 2009.

Submit your article to this journal $\lceil\pi$

Џ Article views: 3

Q View related articles $\square$ 
Charges of greatest Efficacy for Artillery at Sea. 32.5 applicable to the land-service, arranged upon the plan of Sir Home Popham's for the naval service, will be necessary.

When a tent or any other object is fixed upon as a centre-point, it is then gencrally umecessary to use the double ball

When stations are taken below the horizon, the white sides of the balls are to be turned to your correspondent, and it is advantageous to have the men in white or fatigue dresses.

When stations are taken above the horizon, the black sides are to be turned towards your correspondent, aud then it is advantageous to bave the inen in unitorm.$$
\text { I } \mathrm{am} \text {, sir, }
$$$$
\text { Your obedient servant, }
$$
Surry Institurion, Nov. 6,1810
Knight SPencer.

LXI. On the Penetration of Balls into uniform resisting Substances. By W. Moone, Esq.

$$
\text { To Mr. Tillock. }
$$

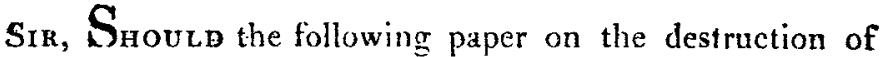
an enemy's vessel at sea by artillery be thought deserving a place in your excellent Marazine, you are at liberty to make use of it aecordingly.

Royal Military Academy,

$$
\text { I ain, sir, }
$$

$$
\text { Your most öbedient servant, }
$$
Woolwich, November 10, 18 io.

W. MOOre.

\section{LEMMA I.}

If two spheres of different diameters and different specific gravities impinge perpendicularly on two uniform resisting fixed obstacles, and fenetrate inlo them; the forces which retard the progress of the spheres will be as the absolute resisting forces or strengths of the fibres of the substances directly, and the diameters and specific gravities of the spheres incersely.

Let $\mathrm{R}$ and $r$ denote the absolute resisting forces of the two substances; $\mathrm{F}$ and $f$ the retarlive forces; $\mathrm{D}, d$ the diameters of the spheres; $Q, q$ their quantities of matter, and $N, n$ their respective specific quantities. Then the whole resistances to the spheres, being by mechanics proportional to the quanti:ies of motion desiroyed in a given time, will be as the absolure resisting forces of the sub. 
326 Charges of greatest Efficacy for Artillery at Sea.

stances and quantities of resisting surfaces jointly; or as the resisting forces of the substances and squares of the diameters of the impinging spheres: that is, $\frac{M}{m}=\frac{R}{r} \times \frac{D^{2}}{d^{2}}$, But in general $\frac{\mathrm{M}}{m}=\frac{\mathrm{F}}{f} \times \frac{\mathrm{Q}}{q}$ : therefore equating these two values of the whole resisting forces, we obtain $\frac{F}{f} \times$ $\frac{\mathbf{Q}}{q}=\frac{\mathrm{R}}{r} \times \frac{\mathrm{D}^{2}}{d^{2}}$, and $\frac{\mathrm{F}}{f}=\frac{\mathrm{R}}{r} \times \frac{\mathrm{D}^{2}}{d^{2}} \times \frac{q}{\mathrm{Q}^{-}}:$and since $\frac{q}{\mathrm{Q}}=\frac{d^{3}}{\mathrm{D}^{3}} \times \frac{n}{\mathrm{~N}}$, it is $\frac{\mathrm{F}}{f}=\frac{\mathrm{R}}{r} \times \frac{\mathrm{D}^{2}}{d^{2}} \times \frac{d^{3}}{\mathrm{D}^{3}} \times \frac{n}{\mathrm{~N}}=\frac{\mathrm{R}}{r} \times$ $\frac{d}{\mathrm{D}} \times \frac{n}{\mathrm{~N}}$ : that is, the forces retarding spheres penetrating unitorm resisting substances are as the absolute strengths of the fibres of the substances directly, and the diameters and specific gravities of the spheres inversely.

\section{LEMMA II.}

The whole spaces or depths ta which spheres impinging on different résictung substances penetrate; are as the squares of the intual relocities, the diameters and specific gravities of the spheres directly, and the alsolute strengths of the resisting substances inversely; or, $\frac{\mathrm{S}}{s}=\frac{\mathrm{V}^{2}}{v^{2}} \times \frac{\overline{\mathrm{D}}}{d} \times \frac{\mathrm{N}}{n} \times \frac{r}{\mathrm{R}}$ :

For by mechanics we have $\frac{\mathrm{S}}{s}=\frac{\mathrm{V}^{2}}{v^{2}} \times \frac{f}{\mathrm{~F}}$; and by the preceding lemma $\frac{f}{\mathrm{~F}}=\frac{r}{\mathrm{R}} \times \frac{\mathrm{D}}{d} \times \frac{\mathrm{N}}{n}$, which substituted in the above it becomes $\frac{\mathrm{S}}{s}=\frac{\mathrm{V}}{v^{2}} \times \frac{\mathrm{D}}{d} \times \frac{\mathrm{N}}{n} \times \frac{r}{\mathrm{R}}$ :

These being premised, I now proceed to resolve the following most iniportant

\section{Problem :}

To'find a general formula which shall express the quantity of charge for any given piece of ordnance to produce the greatest destruction passible to an enemy's ship at sea; it being supposed of oak substance of given thickness, and at a distance not affecting the initial velocity of the shot..

By Lemma 2, we have, generally, $\frac{V^{2}}{v^{2}}=\frac{\mathrm{S}}{s} \times \frac{d}{\mathrm{D}} \times \frac{n}{\mathrm{~N}} \times$ $\frac{R}{r}$. Also the charges of powder vary as the squares of the velocity 
velocity and weight of ball joinlly*. Hence, since it has been deternined from experiment that a charge of half a pound impelled a shot weighing one pound with a velccity of 1600 feet per second; we shall, considering $V$ the velocity of any ball impingiug on the side of the vessel, have for the expression of the charge impelling it through the space $\mathrm{S}=\frac{\mathrm{S} d n \mathrm{R} v^{2} w}{2 \overline{\mathrm{D}} \mathrm{N} r} \times \frac{\operatorname{Tom}^{2}}{10}$

Now to apply this in the present instance, it is first necessary that a case be known concerning the penetration of a given shot into oak. Such a case is presented at page 273 of Dr. Hutton's Robins's New Principles of Gunnery. It is there asserted that an 18-pounder cast-iron ball penctrated a block of well-seasoned rak, such as ships of war are grenerally built with, to the depth of $3 \frac{I}{2}$ inches when fired with a velocity of 400 feet per second. Making, therefore, this the standard of comparison for all cases where the oiject is of oak substance, we shail have for the charge generally $\frac{400^{8} \times 42}{2 \times 1600^{2} \times{ }_{24}^{7}} \times \frac{\mathrm{S} n \mathrm{R} w}{\mathrm{DN} r}$; or, because the balls are of the same specific gravity, and the substance the same, or $\mathrm{R}=r$, and $\mathrm{N}=n$; it will be $\frac{400^{2} \times 42}{2 \times 1600^{2} \times \frac{7}{24}} \times$ $\frac{S w}{D}=0.15 \times \frac{S w}{\mathrm{D}}$; that is the charge varies as the space to be penetrated and weight of ball direclly, and diameter of the ball inversely.

But the charge by the question being to produce the greatent effect possible in the desiruction of the vessel; $S$ in the above formula must always be put equal to the given thickness of its side flus the radius of the ball; snce it is well ascertained that, for a shot to proukce the most damage to any splintering object, such as oak; it must lose all its motion jast as it quils the superior or furtber surface of it. Hence the charge in question is $=.045 \times \frac{\left(\frac{1}{S}+\frac{1}{2} D\right) w}{D} \cdot S^{\prime}$ being the thicknes of the side of the vessel, $w$ the weight of the ball, and $\mathrm{D}$ its diameter.

We have supposed, that the resistance opposed to the ball's motion is uniform throughout the entire penetration;

* This law of variation of the charges does noz exactly obtain in practice after a certain charge, on account of the definite lengths of the guns: b.it it is presumed the deviation from it, if known, would not materially afrect our resulis. 
which is not strictly true; since that resistance depends partly on the quantity of the surface resisted, which continually varies until the ball has penetrated to the depth of its radius; when it continues uniform till it arrives at the further surface of the object; where the rcsistance again commences its variation. These deviations from uniformity are about sufficient to set against that of the law of variation of the charges before mentioned; the velocities from them falling somewhat short of the law there prescribed after a certain charge.

Example I.

An enemy's ship is in sight; required the charge for the 42-pounder guns to destroy her as quickly and completely as possille uhen the ships have approached near to each other: the side of the enemy's vessel (a seventy-four) being $1 \frac{3}{4}$ foot thick of oak timber.

The diameter of a 42 pounder of cast-irun being $=\cdot 557$ foot; we get $\cdot 045 \times \frac{\left(S+\frac{1}{2} D\right) w}{D}=6.88306 \mathrm{lbs}$. or $61 \mathrm{bs}$. 140zs. for the weight of the charge required.

\section{TABLE:}

Containing the various charges for the 12-, 18., 24-, 32-, 36- and 42-pounder guns, for producing the greatest effect in all cases of action: the substance or object being of oak materials, and its thickness together with the radius of the ball from 1 foot to that of 5 feet, regularly increasing by 1 in the inches.

\begin{tabular}{|c|c|c|c|c|}
\hline \multirow{2}{*}{$\begin{array}{c}\text { Nature } \\
\text { of } \\
\text { Ordnance. }\end{array}$} & \multicolumn{4}{|c|}{$\begin{array}{c}\text { Thickness of the Side of the Vessel, plus the } \\
\text { Radilis of the Ball. }\end{array}$} \\
\hline & 12 Inches. & 13 Inches & 1. Inches. & $1 \overrightarrow{0}$ Inches. \\
\hline $\begin{array}{c}\text { Pounder } \\
12\end{array}$ & $\frac{\mathrm{lb} .}{1.439242}$ & $\begin{array}{c}\text { ibs. } \\
1.559178\end{array}$ & $1 \cdot 679116$ & $\begin{array}{c}\text { lbs. } \\
1799052\end{array}$ \\
\hline 18 & $1 \cdot 928571$ & 2089285 & 2249999 & 2410714 \\
\hline 24 & 2336650 & 2.531371 & 2725091 & $2 \cdot 920813$ \\
\hline 32 & 2830470 & 3.066343 & 3.302215 & 3.538058 \\
\hline 36 & 3.061630 & 3.316766 & 3.571901 & 3.827038 \\
\hline 42 & $3 \cdot 393180$ & 3.675949 & 3.958710 & 4.241475 \\
\hline
\end{tabular}


Charges of greatest Efficacy for Artillery at Sea. 399

\begin{tabular}{|c|c|c|c|c|}
\hline \multirow{2}{*}{$\begin{array}{c}\text { Nature } \\
\text { of } \\
\text { Ordnance. }\end{array}$} & \multicolumn{4}{|c|}{$\begin{array}{l}\text { Thickness of the Side of the Vessel, plus the } \\
\text { Ridius of the Bdll. }\end{array}$} \\
\hline & 16 Inches. & 17 linches & 18 Inches. & 19 Inches. \\
\hline $\begin{array}{c}\text { Pounder } \\
12\end{array}$ & $\begin{array}{c}\text { lbs. } \\
1 \cdot 918957\end{array}$ & $\begin{array}{c}\text { lbs. } \\
2 \cdot 838926\end{array}$ & $\begin{array}{c}\text { lbs. } \\
2 \cdot 158863\end{array}$ & $\begin{array}{c}\text { Ths. } \\
2278800\end{array}$ \\
\hline 18 & $2 \cdot 571428$ & 2.732142 & 2.892856 & 3053571 \\
\hline 24 & $3 \cdot 115533$ & $3 \cdot 310: 54$ & 3.504975 & $3 \cdot 69 g 096$ \\
\hline 32 & 3.773900 & $4 \cdot 009833$ & 4245705 & 4.481578 \\
\hline 36 & 4.082173 & 4.337310 & 4.592445 & 4.847581 \\
\hline 42 & 4.524240 & 4.806905 & 5.089770 & 5.372535 \\
\hline
\end{tabular}

\begin{tabular}{|c|c|c|c|c|}
\hline & 20 Inches. & 2! Inches. & 22 Inches. & 23 Inches. \\
\hline 12 & $\begin{array}{c}\text { lhs. } \\
2.398737\end{array}$ & $\begin{array}{c}\text { Mss. } \\
2.518674\end{array}$ & $\begin{array}{c}\text { lbs } \\
2.638612\end{array}$ & $\begin{array}{c}\text { 1bs. } \\
2758547\end{array}$ \\
\hline 18 & 3.214285 & $3 \cdot 374999$ & 3.535714 & $3 \cdot 696428$ \\
\hline 24 & 3.894417 & 4.089137 & $4 \cdot 283859$ & 4.478580 \\
\hline 32 & 4.717 .50 & $4 \cdot 953323$ & $5 \cdot 189195$ & 5.425068 \\
\hline 36 & $5 \cdot 10271\rangle$ & 5.357853 & $5 \cdot 612988$ & 5.868124 \\
\hline 42 & $5.655300 \mid$ & 5938065 & 6.220830 & $6 \cdot 6$ \\
\hline
\end{tabular}

\begin{tabular}{|c|c|c|c|c|}
\hline & 24 Inches. & 25 Incis $>$ s. & 26 Inches. & 27 Inches. \\
\hline 12 & $\begin{array}{c}\text { Ibs. } \\
2 \cdot 878484\end{array}$ & $\begin{array}{c}1 \text { bа. } \\
2998420\end{array}$ & $\begin{array}{c}1.5 \\
3 \cdot 118358\end{array}$ & $\begin{array}{c}\text { J1ss. } \\
3.238292\end{array}$ \\
\hline 18 & 3.857142 & $4 \cdot 017856$ & 4.178570 & $4 \cdot 339284$ \\
\hline 24 & 4.673300 & 4.868021 & $5.0627+11$ & 5.257463 \\
\hline 32 & 5.660940 & 5.896813 & 6.132685 & 6368559 \\
\hline 36 & 6.123260 & 6378396 & 6.633531 & $6 \cdot 888668$ \\
\hline 42 & 6.786360 & 7.069125 & 7351890 & 7.634655 \\
\hline
\end{tabular}


330 Charges of greatest Efficacy for Artillery at Sea.

\begin{tabular}{|c|c|c|c|c|}
\hline \multirow{2}{*}{$\begin{array}{c}\text { Nature } \\
\text { of } \\
\text { Ordnance }\end{array}$} & \multicolumn{4}{|c|}{$\begin{array}{c}\text { Thickness of the Side of the Yessel, plus the Radius } \\
\text { of the Ball. }\end{array}$} \\
\hline & 28 Inches. & 29 Inches. & 30 Inches. & 31 Inches. \\
\hline $\begin{array}{l}\text { Pounder } \\
\quad 12\end{array}$ & $\begin{array}{c}\text { lbs. } \\
3.358228\end{array}$ & $\begin{array}{l}\text { lbs. } \\
3 \cdot 478164\end{array}$ & $\begin{array}{l}\text { lbs } \\
3 \cdot 598100\end{array}$ & $\begin{array}{c}11 . . \\
3 \% \\
718036\end{array}$ \\
\hline 18 & 4.521340 & $4 \cdot 682054$ & $4 \cdot 842768$ & $5 \cdot 003482$ \\
\hline 24 & 5.4 .52184 & $5 \cdot 646905$ & $5 \cdot 841626$ & 6036347 \\
\hline 32 & 6.504432 & 5.840305 & $7 \cdot 076178$ & $7 \cdot 312051$ \\
\hline 36 & $7 \cdot 143804$ & 7396940 & $7 \cdot 654070$ & 7909212 \\
\hline 42 & 7917420 & 8200185 & $8 \cdot 482950$ & 8.765715 \\
\hline
\end{tabular}

\begin{tabular}{|c|c|c|c|c|}
\hline & 32 Inches. & 33 Inches. & 34 Inchis. & 35 Inches. \\
\hline 12 & $\begin{array}{c}\text { llss } \\
3.83797^{2}\end{array}$ & $\begin{array}{c}\text { lbs } \\
3.957908\end{array}$ & $\begin{array}{c}\text { los. } \\
4.0778 .14\end{array}$ & $\begin{array}{c}\text { lhs. } \\
4197780\end{array}$ \\
\hline 18 & $5 \cdot 164196$ & $5 \cdot 324910$ & $5 \cdot 485024$ & $5 \cdot 646338$ \\
\hline 24 & 6.231068 & 6425789 & $6 \cdot 620510$ & $6 \cdot 815231$ \\
\hline 32 & $7 \cdot 547924$ & $7 \cdot 783797$ & 8.019670 & 8.255543 \\
\hline 36 & $8 \cdot 164348$ & $8 \cdot 419484$ & 8674620 & 8.929756 \\
\hline 42 & $9 \cdot 048480$ & 9331245 & $9 \cdot 614010$ & $9 \cdot 806775$ \\
\hline
\end{tabular}

\begin{tabular}{|c|c|c|c|c|}
\hline & 36 Inches. & 37 Inches. & 38 Inches. & 39 Inches. \\
\hline 12 & $\begin{array}{c}\text { lbs. } \\
4317716\end{array}$ & $\begin{array}{c}\text { lbs. } \\
4437652\end{array}$ & $\begin{array}{c}\text { lbs. } \\
4.537588\end{array}$ & $\begin{array}{c}\text { lbs. } \\
4.677524\end{array}$ \\
\hline 18 & 5807052 & 5.967766 & $6 \cdot 128480$ & 6289194 \\
\hline 24 & 7009952 & $7 \cdot 204673$ & $7 \cdot 399394$ & $7 \cdot 594115$ \\
\hline 32 & 8.491416 & $8 \cdot 727^{\prime 289}$ & $8 \cdot 963162$ & $9 \cdot 199035$ \\
\hline 36 & $9 \cdot 184892$ & $9 \cdot 440028$ & $9 \cdot 695164$ & 9950300 \\
\hline 42 & $10 \cdot 179540$ & 10462305 & 10745070 & 11027835 \\
\hline
\end{tabular}


Charges of greatest Efficacy for Artillery at Sea.

\begin{tabular}{|c|c|c|c|c|}
\hline \multirow{2}{*}{$\begin{array}{c}\text { Nature } \\
\text { of } \\
\text { Ordnance. }\end{array}$} & \multicolumn{4}{|c|}{$\begin{array}{c}\text { Thickness of the Side of the Vessel, plus the Radiu } \\
\text { of the Ball. }\end{array}$} \\
\hline & 40 Inches. & 41 inches. & 42 Inches. & 43 Inches. \\
\hline $\begin{array}{l}\text { Pounder } \\
12 .\end{array}$ & $\begin{array}{c}\text { lbs. } \\
4797460\end{array}$ & $\begin{array}{c}\text { lbs. } \\
4 \cdot 917396\end{array}$ & $\begin{array}{c}\text { lbs. } \\
5.037332\end{array}$ & $\begin{array}{ll}\text { lbs. } \\
5 \cdot 157268\end{array}$ \\
\hline 18 & 6.449908 & $6 \cdot 610622$ & 6771336 & 6.932050 \\
\hline 24 & 7788836 & 7953557 & $8 \cdot 178278$ & 8.372999 \\
\hline 32 & .9434908 & 9670781 & 9906654 & 10142527 \\
\hline 36 & $10 \cdot 205436$ & $10460 \div 72$ & 10715708 & 10.970844 \\
\hline 42 & $11 \cdot 310600$ & $11 \cdot 593365$ & 11.876130 & 12158895 \\
\hline
\end{tabular}

\begin{tabular}{|c|c|c|c|c|}
\hline & 14 Inches. & 45 Inches. & 46 Inches. & 47 Inches. \\
\hline 12 & 5.277204 & 5.397140 & 5.517076 & $\begin{array}{c}\text { Ibs. } \\
5.637012\end{array}$ \\
\hline 18 & 7.092764 & 7.253478 & 7.414192 & 7.574906 \\
\hline 24 & 8.507720 & $8 \cdot 762141$ & 8957162 & 9151883 \\
\hline 32 & 10378400 & 10.614273 & $10.850 ! 46$ & 11086019 \\
\hline 36 & 11.225980 & 11.481116 & 11.736252 & $11 \cdot 991338$ \\
\hline 42 & 12.441660 & 12.724425 & 13.007190 & 13.289955 \\
\hline
\end{tabular}

\begin{tabular}{|c|c|c|c|c|}
\hline & 48 Inches. & 49 Inches. & 50 Inches. & 51 Inches. \\
\hline 12 & $\begin{array}{c}16 \times . \\
5 * 750948\end{array}$ & $\begin{array}{ll}\text { lbs } \\
5876884\end{array}$ & $\begin{array}{c}\text { the } \\
5 \cdot 996820\end{array}$ & $\begin{array}{c}\text { lbs. } \\
6116756\end{array}$ \\
\hline 18 & $7 \cdot 735620$ & $7 \cdot 896334$ & 8.057048 & 8217762 \\
\hline 24 & 9346604 & 9.541325 & 9736046 & 9.930767 \\
\hline 32 & 11321802 & 11.557765 & $11 \cdot 703638$ & $12 \cdot 029511$ \\
\hline 36 & $12 \cdot 246524$ & 12.501660 & 12756796 & $13 \cdot 011932$ \\
\hline 42 & $13.5727^{20}$ & $13 \cdot 855185$ & 14138250 & 14421015 \\
\hline
\end{tabular}


332 Charges of greatest Efficacy for Artillery at Sea.

\begin{tabular}{|c|c|c|c|}
\hline \multirow{2}{*}{$\begin{array}{c}\text { Nature } \\
\text { of } \\
\text { Ordnance. }\end{array}$} & \multicolumn{3}{|c|}{$\begin{array}{c}\text { Thickness of the Side of the Vessel, plus } \\
\text { the Radius of the B..1! }\end{array}$} \\
\hline & 52 Inches. & 53 Inches. & 54 Inches. \\
\hline $\begin{array}{l}\text { Pounder } \\
12\end{array}$ & $\begin{array}{l}\text { lbs. } \\
6 \cdot 236692\end{array}$ & $\begin{array}{l}\mathrm{lbs} \\
6 \cdot 356628\end{array}$ & 1bs: \\
\hline 18 & 8.378476 & 8.539190 & $8 \cdot 699904$ \\
\hline 24 & 10125488 & 10320209 & 10.514930 \\
\hline 32 & $12 \cdot 265384$ & 12.5012 .57 & 12737130 \\
\hline 36 & $13 \cdot 267068$ & 13.522204 & 13.777340 \\
\hline 42 & 14703780 & $14 \cdot 986545$ & $15 \cdot 209310$ \\
\hline
\end{tabular}

\begin{tabular}{|c|c|c|c|}
\hline 1 & 55 Inches. & 56 Inches. & 57 Inches. \\
\hline 12 & $\begin{array}{c}\text { lbs. } \\
6596500\end{array}$ & $\begin{array}{l}\text { Ibs. } \\
6.716436\end{array}$ & $\begin{array}{c}\text { lbs. } \\
6.836372\end{array}$ \\
\hline 18 & 8.860618 & $9^{\circ} 021332$ & $9 \cdot 182046$ \\
\hline 24 & 10709651 & 10904372 & $11 \cdot 099093$ \\
\hline 32 & $12 \cdot 973003$ & $13 \cdot 208876$ & $13 \cdot 444749$ \\
\hline 36 & 14.032476 & 14287612 & 14542748 \\
\hline 42 & 15.552070 & 15.834840 & 16.117605 \\
\hline
\end{tabular}

\begin{tabular}{|c|c|c|c|}
\hline & 58 Inches. & 59 Inches. & 60 Inches. \\
\hline 12 & $\begin{array}{c}\text { lbs. } \\
6.956308\end{array}$ & $\begin{array}{c}\text { lbs. } \\
7 \cdot 076244\end{array}$ & $\begin{array}{c}\text { lbs. } \\
7 \cdot 196180\end{array}$ \\
\hline 18 & 9342760 & $9 \cdot 503474$ & 9664188 \\
\hline 24 & $11 \cdot 2938 \div 4$ & $11 \cdot 488535$ & 11683256 \\
\hline 32 & 10680622 & 13916495 & $14 \cdot 152368$ \\
\hline 36 & 14.797884 & $15 \cdot 053028$ & 15308156 \\
\hline 42 & 16.400370 & 16.683135 & 16.965900 \\
\hline
\end{tabular}


In this Table the first column contains the nature of the ordrance, and the numbers in the other columns are their respective charges of gumpowder in pounds, when the thickness of the object to be destroyed is as specified at the top of the columns. If the thickness be given in inches, and parts of inchis, $t$ ike such parts of the difference between the charge for the given number of inches and the next greater; and add them to the charge first found for the given number of inches for the charge required.

The value of the decimal part of each will be bad by multiplying it by 16 , the number of nunces in a pound, and pointing off in the product from the right hand towards the left, as many places for decimals as are contained in the given decimal, and retaining the number on the left of the point for the ounces, increasing it by $\frac{1}{4}, \frac{1}{2}, \frac{3}{4}$, or 1 , when the first figure of the decimal is $2,5,7$ or 8 respectively. This hint is merely g ven for those practitioners who may not be very conversaut in decimals.

\section{Schotium.}

This question is not only of the utmost importance and practically useful in naval engagements, but in several instances also of military operations; as the bursting open gates of besieged ciries with promptitude and effect, and breaking up all fortifications composed of wooden materials; especially those of a splintering nature, to which the above charges apply most currectly. In the case of a naval action where the ohject to be penetrated is of oak substance, the ball by having a small motion when it quits the ship's side tears anci splinters it excessively, brcaking away large pieces before it, which are not so easily supplied in the reparation: whereas on the other hand, if the shot had any considerable velocity when it quitied the side, the. effect produced would be merely a hole, which would be stopped instantly by the mechanic employed for that purpose; and indeed in a grat measure by the springiness of the wood itself; for 1 have scen in his majesty's dock-yard at Woolwich, captured vesse's having a number of shotholes in them, almost entirely closed by the wood's own efforts; and that requed nothing more than a small wooden peg or a piece of crik to stop them up perfecty: all the damage, therefore, the whot can do under such circumstances of swift celerity is merely killing those men who may chance to stand in the way of their motion.

If any object to be destroyed he so thick that it canrot be completely pierced by any common engine; or if it be 


\section{Charges of greatest Efficacy for Artillery at Sca.}

of a very brittle nature, such as stone or brick, then that charge is to be used which will give the greatest velocity to the shot to produce the maximum effect. But in many cases of bombardment this charge is by no means to be preferred; for though the effect produced each individual time be greater, yet in any considerable time the whole effect would be less than that from a smaller charge oftener fired, on account of the extreme heat it would give to the engine after a few discharges; and in consequence of which greater time would be required for cooling the gun and preparing it for further service.

\section{Example II.}

Required the charge for a 24-pounder shot to burst open the gates of a cily with the greatest ease possible, they being of elm one foot thick.

Here the object to be penetrated being elm, the small letters in the general formula $\frac{S d v^{2} w}{2 \mathrm{D} s \times 1600^{2}}\left(=\frac{\left(\frac{1}{S}+\frac{1}{2} \mathrm{D}\right) d v^{q} w}{2 \mathrm{D} s \times 1600^{2}}\right)$ : must be made to denote the several numbers of some experiment made in the penetration of this substance. Taking, therefore, the experiment of Dr. Hutton contained in the 5 th problem of his elegant Exercises on Forces, we have $d=\frac{1}{6} \mathrm{ft} . v=1500$, and $\mathrm{S}=\frac{13}{12} \mathrm{ft}$; also by the question $\mathrm{S}=1 \mathrm{ft} . \mathrm{D}=\cdot 46$, and $w=24] \mathrm{bs}$. therefore $\frac{\left(\mathrm{S}+\frac{1}{2} \mathrm{D}\right) d v^{2} w}{2 \mathrm{D} s \times 1600^{3}}$ $=\frac{1.23 \times \frac{1}{6} \times 1500^{2} \times 24}{2 \times 46 \times 13 \times 1600^{2}}=\frac{830 \cdot 25}{191 \cdot 36}=4.33868 \mathrm{lbs}$. or $4 \mathrm{lbs}$. $5 \frac{1}{2}$ ozs. nearly the weight of the charge required in this case.

Retaining the experiment of Dr. Hutton as a standard for all cases where the substance to be penetrated is of elm, we shall have by reduction $\frac{\left(S^{\prime}+\frac{1}{2} \mathrm{D}\right) d v^{2} w}{2 \mathrm{D} s \times 1600^{2}}=.0676 \times \frac{\left(\mathrm{S}^{\prime}+\frac{1}{2} \mathrm{D}\right) w}{\mathrm{D}}$ : the charge for any piece the diameter of whose shot is $D$, and weight $w ; \mathrm{S}$ being the thickness of the object as before.

It is not unworthy of remark, that the gates of a besieged place, or any like things, might be effectually broken open by the gun itself, charged only with powder; by placing it dose to the gates with its muzzle from them; the monentum of recoil being generally sufficient to force such ojects completely. 